\title{
Multivariate analysis of the milk coagulation process in ovine breeds from Spain
}

\author{
J. Caballero-Villalobos, ${ }^{* 1}$ A. Figueroa, ${ }^{*}$ K. Xibrraku, $†$ E. Angón, ${ }^{*}$ J. M. Perea, ${ }^{*}$ and A. Garzón* \\ *Departamento de Producción Animal, Universidad de Córdoba, Córdoba 14071, Spain \\ †Technological Educational Institute of Epirus, Arta 47100, Greece
}

\begin{abstract}
In Spain, ewe milk is mainly used for cheesemaking, and farming systems have traditionally been based on the use of autochthonous breeds. However, in recent years, the progressive introduction of highly productive foreign breeds in Spanish farms has led to an increasing interest in the characterization of dairy sheep breeds to evaluate whether genetic selection schemes should focus on productivity or milk technological aptitude. The purpose of this work was to explore milk composition and coagulation to classify 4 of the main dairy sheep breeds used in Spain. This study included 832 individual ewe milk samples from the breeds Manchega, Assaf, Merino de Grazalema, and Merino de Los Pedroches. Samples were analyzed for native $\mathrm{pH}$, composition (fat, protein, lactose, and total solids), coagulation properties, and individual laboratory curd yield. An indicator of coagulation efficiency was also determined. Canonical discriminant analysis was performed to establish differences and similarities among breeds based on the measured variables. In addition, cluster analysis was performed to study and quantify the concrete relationships among the discriminated groups. Discriminant analysis proved to be a powerful tool to accurately draw distinctions between breeds. In all cases, discrimination among breeds was evident and the 4 breeds could be easily differentiated. Cluster analysis showed greater similarity between Merino de Grazalema and Assaf compared with the other breeds, and $F$-statistics indicated a higher discriminating ability for the variables related to milk composition. However, Merino de Grazalema and Manchega were difficult to separate according to milk composition, but the coagulation process differenced them clearly. Coagulation also evidenced similarities between Manchega and Merino de Los Pedroches, although the latter was revealed to be the most different breed of all 4 , which
\end{abstract}

Received March 15, 2018.

Accepted August 21, 2018.

${ }^{1}$ Corresponding author: v22cavij@uco.es could lay the ground for its differentiation as an independent breed in the Official Catalogue of Spanish Livestock Breeds.

Key words: sheep, milk coagulation, breed, multivariate analysis

\section{INTRODUCTION}

Spain holds one of the highest dairy sheep livestock counts in Europe, with 2,224,465 ewes in production (FAOSTAT, 2018). This is reflected in dairy production, which in 2015 reached a volume of 440,915 t, representing $17 \%$ of the European ewe milk production (Inlac, 2015). Sheep milk production in the European Union, particularly in southern countries, has historically been based on the farming of autochthonous breeds (Milán et al., 2011; Pazzola et al., 2018). Native breeds such as Spanish Manchega and Italian Sarda of French Lacaune are of great economic importance, and their products have long been deeply embedded in the Mediterranean agricultural culture and tradition (Boyazoglu and Morand-Fehr, 2001; Toro-Mujica et al., 2011; Pazzola et al., 2014). These local breeds are usually well adapted to the climate and environmental conditions of their production areas, but milk yields are often low (De la Fuente et al., 2006).

Because of this, genetic selection schemes started to develop in the late 1980s and were progressively implemented by breeder associations to improve productivity in dairy flocks (Gallego et al., 2016). However, due to the high costs of implementation and the low milk yields, selective breeding in small ruminants is less developed than in dairy cattle (Bittante et al., 2017). In addition, in most of these programs, selection criteria have always been focused on the obtainment of higher yields (Barillet, 2007) without engaging in qualitative control of milk compositional or technological properties (Bittante et al., 2017). For this reason, in the last decades several foreign sheep breeds have been introduced in Spanish farms to enhance milk production. Such is the case of Assaf, introduced in the Iberian Peninsula in the late 1970s and formally recognized in 2003 in the 
Official Catalogue of Spanish Livestock Breeds (Legaz et al., 2011).

As in many Mediterranean countries, in Spain practically the entire production of sheep milk is intended for cheesemaking, whether in pure form or mixed with goat or bovine milk (Jaramillo et al., 2008). Therefore, the quality of raw milk is essential to obtain high cheese yields (Pazzola et al., 2018). This important cheese production is a major component of the southern European ovine industry and in the last few years has been strengthened by the emergence of the protected designations of origin (PDO) and the protected geographical indications (PGI), which ensure control of production and processing factors and guarantee consumers a high quality of the products (Gaspar et al., 2011). The increasing development of these and other quality marks has also contributed to the recovery of endangered autochthonous breeds. A good example is the case of Merino de Grazalema, a breed that currently shows evident signs of recovery due to continued support from public administrations and the recent founding of its own breeders' association (Molina et al., 2005). In addition, other native breeds such as Spanish Merino are initiating a strong development in some regions of southwest Spain, which could contribute to their differentiation and recognition as new varieties in the Official Catalogue of Spanish Livestock Breeds. However, although many studies performed on dairy cows have characterized milk for PDO and PGI products, this information regarding small ruminant milk is scarce, and further knowledge would contribute to the improvement of the ovine cheese industry (Bittante et al., 2011, 2017).

All these facts have increased the interest of consumers and have opened broader debate on whether selection programs in dairy ewes should focus on milk quantity or quality (Arrebola et al., 2007). As these criteria have not been completely defined, milk properties of many Spanish dairy sheep breeds have not yet been studied. The main objective of this study was to classify 4 of the main dairy sheep breeds used in Spain based on their milk composition and coagulation process.

\section{MATERIALS AND METHODS}

\section{Animals, Breeds, and Management Systems}

The breeds included in this study were Manchega, Assaf, and 2 Spanish varieties of Merino sheep (Grazalema and Pedroches). Manchega represents one of the most important national breeds due both to its numbers and its production (Arias et al., 2012). In the Official Catalogue of Spanish Livestock Breeds it is classified as a local enhancement breed (MAPAMA, 2018). Its great importance lies in its adaptation to a dry and difficult environment and in its influence on the improvement of other Spanish local ovine breeds (Rivas et al., 2014). The farming system is semiextensive, based on continuous pasturing during the whole year to maximize the use of natural resources (Morantes et al., 2017). According to the breeders' association, milk yield in Manchega is estimated to be around $240 \mathrm{~L} /$ lactation (ESROM, 2015). Manchega can be found in 42 of the 50 Spanish provinces, although the highest concentration involves the region of Castilla-La Mancha. Milk from this breed is used to manufacture PDO cheese queso Manchego, probably the most important and best-known product of the agrifood sector of Castilla-La Mancha (Arias et al., 2013).

Assaf is a native breed from Israel, originated from the successive crossbreeding between the breeds Awassi and Milschschaf. Assaf was introduced in Spain in 1977 and is currently cataloged as a third country breed (MAPAMA, 2018). Animals from this breed are characterized by long lactations, high milk yields (359 L/ lactation), and good adaptation to intensive production systems (De la Fuente et al., 2006). Consequently, Assaf has been crossbred with other Spanish native breeds with a view to enhance milk production and to improve the dairy morphotype, allowing a better adaptation of the udder to mechanical milking (Pérez-Cabal et al., 2013). These enabling characteristics, together with the strong settlement of the breed in the last $30 \mathrm{yr}$, led in 2015 to the authorization of the use of milk from Assaf crossbred ewes for the manufacture of the PDO cheese queso Zamorano (European Union, 2015).

Merino de Grazalema is a Spanish variety of Merino currently considered to be an independent breed in the Official Catalogue of Spanish Livestock Breeds (MAPAMA, 2018). It has been classified as an endangered native breed. Merino de Grazalema is noted for its rusticity and good dairy aptitude (118.3 L/lactation) and is usually integrated into extensive or semiextensive farming systems, mainly adapted to organic or sustainable production (Casas et al., 2005). Animals from this breed are greatly adapted to cold and damp winters and make use of the native resources as the basis for their diet (García Romero et al., 2017). The expansion area of the breed is mainly centered in the natural park Sierra de Grazalema, located between the southern provinces of Cádiz and Málaga. However, small herds can also be found in other areas of southwest Spain (Molina et al., 2005). In recent years, the manufacture of Grazalema cheese has been strengthened, and a PDO for cheese made with milk from this breed is currently being ratified (Moreno and Aguilar Criado, 2012). 
Merino de Los Pedroches represents an important nucleus of Merino sheep from the region Valle de Los Pedroches, in the north of the province of Córdoba (Arrebola, 2004). It has not been officially cataloged as an independent breed, but in recent years the increasing improvement and selection of ewes toward dairy specialization makes it worth comparing with other sheep breeds in this study. Yield in Spanish Merino has been estimated to be around 30 to $50 \mathrm{~L} /$ lactation, and cheeses manufactured with this milk can vary from a hard-pressed paste cheese to a softer torta cheese, both made from raw or pasteurized milk (Ordiales et al., 2013).

\section{Collection of Milk Samples}

This study included 832 individual ewe milk samples collected in 2015 and 2016. All samples were collected from the morning milking and stored at $4^{\circ} \mathrm{C}$ in hermetically sealed containers until analysis. The experimental design was based on flocks with a single ovine breed. To determine the effect of breed, 32 single-breed flocks were randomly selected: 8 Manchega flocks from the region of Castilla-La Mancha, 8 Merino de Grazalema flocks from the province of Cádiz, 8 Merino de Los Pedroches flocks from the province of Córdoba, and 8 Assaf flocks from the region of Castilla y León. Twentysix multiparous sheep were randomly selected from each herd, and the total number of milk samples per breed was 208.

\section{Laboratory Analysis}

All analyses were performed in the Dairy Small Ruminant Laboratory (Universidad de Córdoba, Spain) within $5 \mathrm{~h}$ from milk collection. Native $\mathrm{pH}$ of milk was measured with a Crisson Basic20 pH meter (Crisson Instruments S.A., Barcelona, Spain), and major milk components (fat, protein, lactose, and TS) were directly determined by mid-infrared spectroscopy using a MilkoScan FT120 (Foss Electric, Hillerød, Denmark). Milk coagulation properties were monitored at $32^{\circ} \mathrm{C}$ using a Formagraph viscometer (Foss Electric) following the method developed by McMahon and Brown (1982) with modifications described by Caballero-Villalobos et al. (2018). This method is based on the oscillatory motion of circular pendula immersed in milk during coagulation; information is then transferred to a computer, where the result of the pendulum movements is represented in a diagram. The conditions for the analysis of milk coagulation properties were established taking as reference the manufacturing conditions of Manchego cheese, reflected in the product specification of the
PDO queso Manchego (Government of Spain, 2007). The testing time of the analysis was set up at $60 \mathrm{~min}$, and milk coagulation was initiated by the addition of 50 $\mu \mathrm{L}$ of a $4 \%$ dilution of single-strength liquid animal rennet dilution (185 international milk coagulating units/ $\mathrm{mL}$ ). All milk samples used in this study were coagulated under these laboratory conditions. The measured parameters included rennet clotting time $(\mathbf{R C T})$, curd firming time, and curd firmness at $60 \mathrm{~min}\left(\mathbf{A}_{\mathbf{6 0}}\right)$. The ratio $\mathrm{RCT}: \mathrm{A}_{60}$ was used as an indicator of coagulation efficiency, as described in Caballero-Villalobos et al. (2018). After rennet coagulation, individual laboratory cheese yield (ILCY) was measured following the methodology first described by Othmane et al. (2002), with slight modifications (Caballero-Villalobos et al., 2018b): the resulting gels were cut with a spatula and centrifuged for $30 \mathrm{~min}$ at $2,800 \times g$ and $37^{\circ} \mathrm{C}$ to separate the curd from the whey. Finally, the centrifuge residues (drained curds) were individually weighed to estimate ILCY (expressed in $\mathrm{g} / 10 \mathrm{~mL}$ ).

\section{Statistical Analysis}

Preliminary testing of data was carried out to determine outliers to be discarded before further analysis. Because data had different units of measurements, they were standardized to zero mean and a unit standard deviation. The common descriptive characteristics of the studied variables are shown in Table 1.

Differences and similarities in the milk composition and coagulation process obtained for each breed were analyzed using canonical discriminant analysis (Everitt and Dunn, 1991; Tabachnick and Fidell, 1996). The first step in the canonical discriminant analysis was to determine the a priori basis for grouping the breeds. The analysis was performed on 3 sets of variables: those related to milk composition, those related to milk rennet coagulation, and the whole set of variables. The

Table 1. Variables used to differentiate between ovine breeds $(\mathrm{n}=$ 832)

\begin{tabular}{lrr}
\hline Variable & Mean & SD \\
\hline Milk composition & & \\
Fat, \% & 7.18 & 1.71 \\
CP, \% & 5.60 & 0.66 \\
Lactose, \% & 4.99 & 0.68 \\
TS, \% & 18.86 & 2.25 \\
pH, -log [H $\left.{ }^{+}\right]$ & 6.69 & 0.12 \\
Coagulation process & & \\
Rennet clotting time, min & 30.68 & 9.84 \\
Curd firming time, min & 4.67 & 1.97 \\
Curd firmness at 60 min, mm & 52.24 & 14.98 \\
Curd yield, g/10 mL of milk & 3.18 & 0.69 \\
Coagulation efficiency at 60 min & 0.89 & 0.68 \\
\hline
\end{tabular}


Table 2. Results from the canonical discriminant analysis for composition variables, coagulation traits, and the whole set of variables

\begin{tabular}{lccccc}
\hline Model & $\begin{array}{c}\text { Variables in } \\
\text { model, no. }\end{array}$ & $\begin{array}{c}\text { Groups, } \\
\text { no. }\end{array}$ & $\begin{array}{c}\text { Wilks' } \\
\text { lambda }\end{array}$ & $F$-value & $P$-value \\
\hline Both sets & 10 & 4 & 0.031 & $F(181.019)=1.464$ & $<0.0001$ \\
Composition & 5 & 4 & 0.115 & $F(164.795)=1.422$ & $<0.0001$ \\
Coagulation & 5 & 4 & 0.232 & $F(105.910)=1.671$ & $<0.0001$ \\
\hline
\end{tabular}

efficiency of the discriminative power of a given model was determined by the test of significance of the Wilks' lambda value. The predictive ability for each model was tested using the absolute assignment of individuals to the preassigned group. The distances among groups were determined using the Mahalanobis distances and their statistical significance. Stepwise discriminant analysis was used to determine the discrimination ability of the variables, either forward or backward. In addition, the Student-Newman-Keuls test was used to determine the existence of significant differences between breeds. A complete description of the method can be found in Herrera et al. (1996) and Rodero et al. (2012) among others.

The second step was the study of the concrete relationships that exist among the discriminated groups. Cluster analysis was appropriate because it provides not only a simple representation of the groups but also a quantification of the relationships among these groups (Tabachnick and Fidell, 1996) and complements the discriminant analysis because the latter explores only associations between data without explaining why they exist. In this research, we have used the joining tree clustering method, which is based on a plot that shows linkage distances along the vertical axis. Every node in the representation points out where a cluster is defined. When the data have a structure, with groups of similar elements, this grouping structure is established in the hierarchical tree in the form of different branches. Euclidean distances were used for the analysis (ZuritaHerrera et al., 2011).

Clustering analysis was carried out among the groups formed with individuals belonging to each breed. These analyses were developed using the individual Mahala- nobis distances performed in the canonical discriminant analysis and were carried out for variables related to milk composition, variables related to the coagulation process, and the whole set of variables. All statistical analyses were performed using SAS version 5 for Windows (SAS Institute Inc., Cary, NC).

\section{RESULTS}

Table 2 shows the general results obtained from the canonical discriminant analysis with all the measured variables and with variables from the 2 stages (milk composition and coagulation traits). In all cases, discrimination among breeds was evident because the $F$ statistics of the Wilks' lambda were always significant for the first discriminant variable.

Analysis of variability among all coagulation variables indicated that these 4 breeds could be easily differentiated. This outcome is supported by the Mahalanobis distances between groups (Table 3) and in the classification matrix of each ewe into its preassigned group (Table 4), which shows that the distances among groups were significant and that $95.55 \%$ of ewes were correctly assigned. This is more evident in the graphic representation of the results in 2 dimensions (Figure 1).

Cluster analysis supported these findings, as the Euclidean distances obtained resulted in clear divisions between groups, which can be easily appreciable (Figure 2). Cluster analysis showed greater similarity between the breeds Merino de Grazalema and Assaf (linkage distance $=27.064$ ) compared with the breeds Manchega (linkage distance $=239.142$ ) and Merino de los Pedroches (linkage distance $=643.136$ ), which were considerably distant from the first 2 breeds.

Table 3. Mahalanobis distances between the studied sheep breeds ${ }^{1}$ for milk coagulation variables (under the diagonal), milk composition variables (under the diagonal in parentheses), and both sets of variables (above the diagonal $)^{2}$

\begin{tabular}{lcccr}
\hline Breed & $\mathrm{M}$ & $\mathrm{G}$ & $\mathrm{P}$ & $\mathrm{A}$ \\
\hline $\mathrm{M}$ & $11.541(1.023)$ & 15.838 & 26.930 & 16.759 \\
$\mathrm{G}$ & $1.532(24.173)$ & $7.460(23.903)$ & 33.572 & 6.969 \\
$\mathrm{P}$ & $11.436(4.278)$ & $1.017(6.304)$ & $8.895(14.934)$ & 22.874 \\
$\mathrm{~A}$ & & \\
${ }^{1} \mathrm{M}=$ Manchega; $\mathrm{G}=$ Merino de Grazalema; $\mathrm{P}=$ Merino de Los Pedroches; $\mathrm{A}=$ Assaf. & \\
${ }^{2}$ All distances are significant at $P<0.001$. &
\end{tabular}



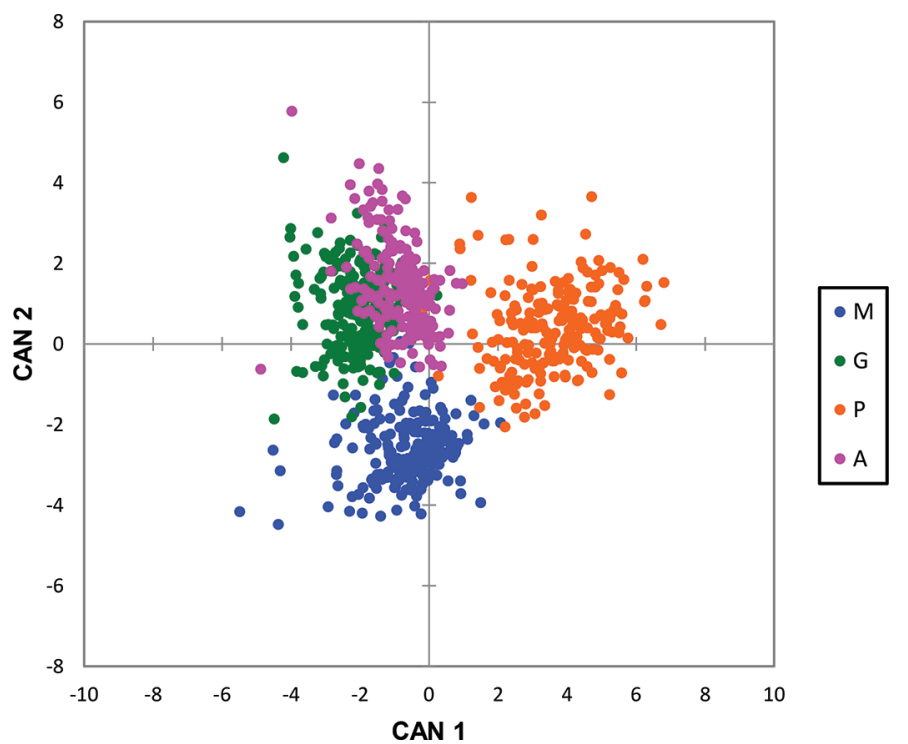

Figure 1. Graphic representation of the results from canonical discriminant analysis for both sets of variables, defined by the axes of the 2 first canonical variables (CAN 1 and CAN 2). M = Manchega, $\mathrm{G}=$ Merino de Grazalema, $\mathrm{P}=$ Merino de Los Pedroches, $\mathrm{A}=$ Assaf. Color version available online.

The $F$-statistics indicated a higher discriminating ability for the variables related to milk composition. This can also be observed in Tables 3 and 4, where the magnitude of the Mahalanobis distances diminishes and the correct assignment of ewes to groups based on predictions is reduced. The breeds Manchega and Merino de Grazalema are difficult to separate according to

Table 4. Percentage classified into breed assignment error levels

\begin{tabular}{lrrrr}
\hline Breed $^{1}$ & \multicolumn{1}{c}{$\mathrm{M}$} & $\mathrm{G}$ & $\mathrm{P}$ & \multicolumn{1}{c}{$\mathrm{A}$} \\
\hline Both sets & & & & \\
$\mathrm{M}$ & 98.06 & 1.39 & 0.50 & 0.95 \\
$\mathrm{G}$ & 0.49 & 90.28 & 0.00 & 5.69 \\
$\mathrm{P}$ & 0.97 & 0.46 & 99.50 & 3.32 \\
$\mathrm{~A}$ & 0.49 & 7.87 & 0.00 & 90.05 \\
Error level & 0.03 & 0.06 & 0.05 & 0.09 \\
Priors & 0.25 & 0.25 & 0.25 & 0.25 \\
Composition & & & & \\
M & 61.06 & 22.60 & 0.00 & 16.35 \\
G & 24.52 & 69.23 & 0.00 & 6.25 \\
P & 0.96 & 0.48 & 91.83 & 6.73 \\
A & 8.17 & 2.40 & 0.00 & 89.42 \\
Error level & 0.39 & 0.31 & 0.08 & 0.10 \\
Priors & 0.25 & 0.25 & 0.25 & 0.25 \\
Coagulation & & & & \\
M & 76.02 & 0.47 & 17.26 & 2.50 \\
G & 0.00 & 65.42 & 7.61 & 26.50 \\
P & 20.36 & 6.54 & 73.60 & 2.00 \\
A & 3.62 & 27.57 & 1.52 & 69.00 \\
Error level & 0.19 & 0.33 & 0.30 & 0.34 \\
Priors & 0.25 & 0.25 & 0.25 & 0.25 \\
\hline
\end{tabular}

${ }^{1} \mathrm{M}=$ Manchega; $\mathrm{G}=$ Merino de Grazalema; $\mathrm{P}=$ Merino de Los Pedroches; $\mathrm{A}=$ Assaf.

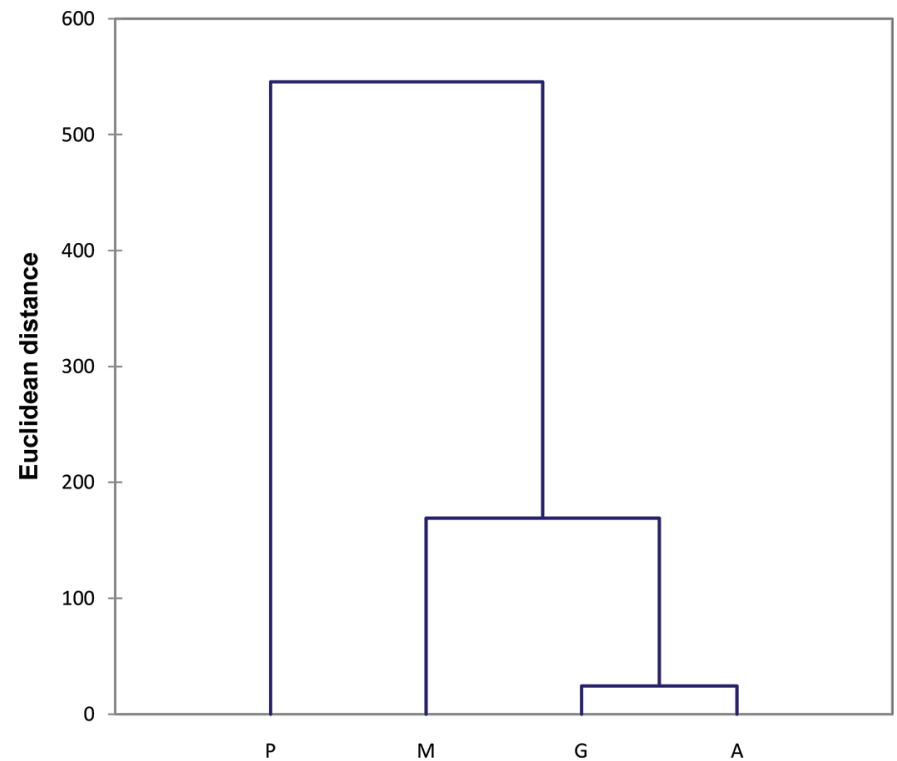

Figure 2. Representation of the results from cluster analysis for both sets of variables (composition and coagulation). $\mathrm{P}=$ Merino de Los Pedroches, $\mathrm{M}=$ Manchega, $\mathrm{G}=$ Merino de Grazalema, $\mathrm{A}=$ Assaf. Color version available online.

milk composition (Figure 3), whereas the coagulation process differenced them clearly (Figure 4 ). In addition, coagulation defines 2 groups of breeds: Merino de Grazalema and Assaf on one side, and Manchega and Merino de Los Pedroches on the other side.

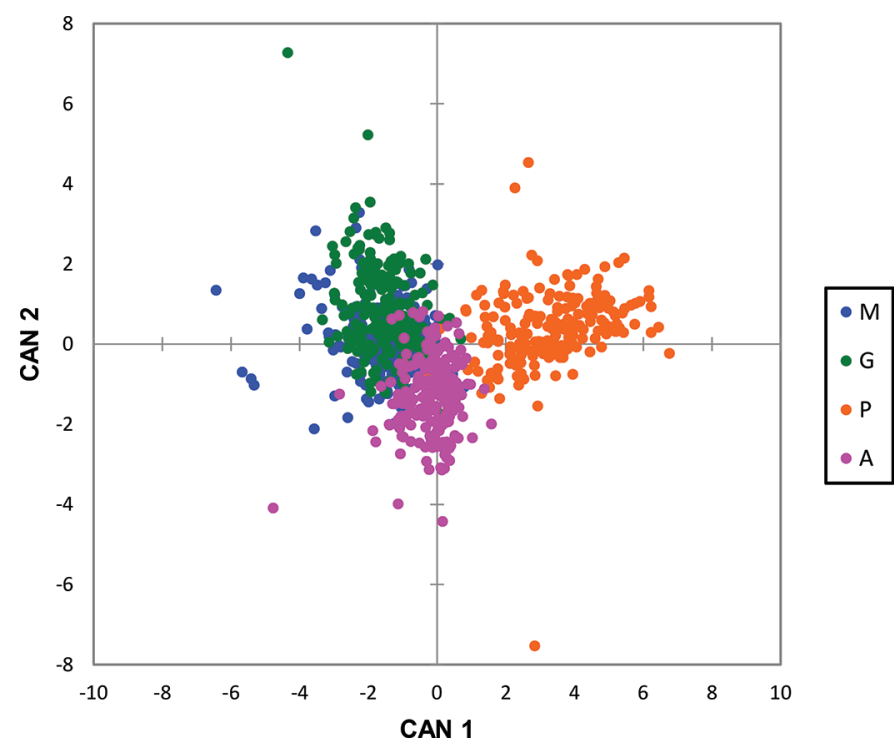

Figure 3. Graphic representation of the results from canonical discriminant analysis for milk composition variables, defined by the axes of the 2 first canonical variables (CAN 1 and CAN 2). $\mathrm{M}=$ Manchega, $\mathrm{G}=$ Merino de Grazalema, $\mathrm{P}=$ Merino de Los Pedroches, $\mathrm{A}=$ Assaf. Color version available online. 

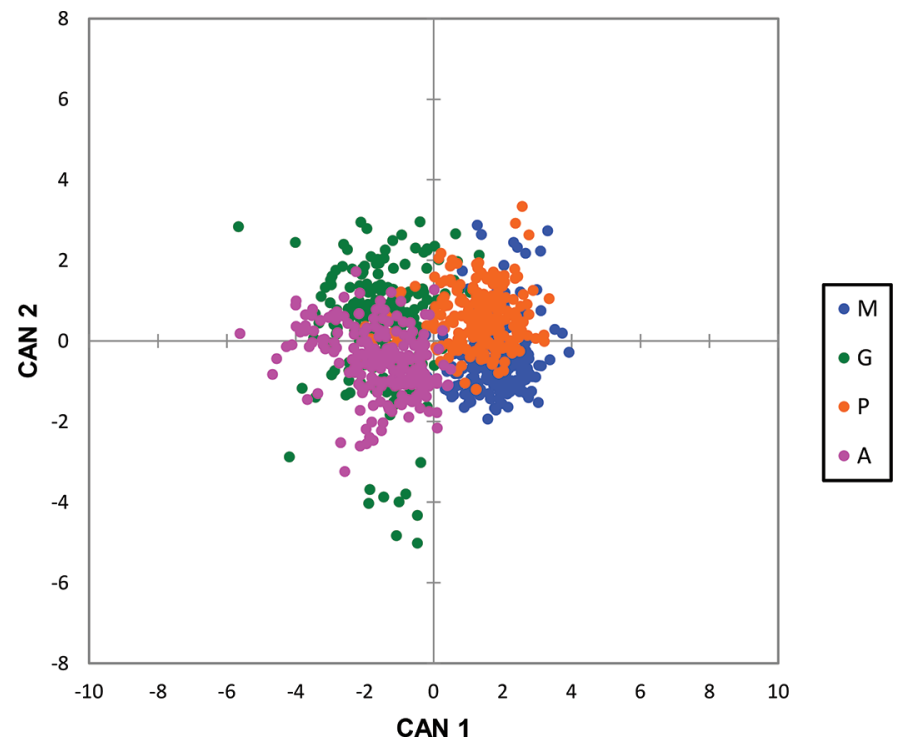

Figure 4. Graphic representation of the results from canonical discriminant analysis for milk coagulation variables, defined by the axes of the 2 first canonical variables (CAN 1 and CAN 2). $\mathrm{M}=$ Manchega, $\mathrm{G}=$ Merino de Grazalema, $\mathrm{P}=$ Merino de Los Pedroches, $\mathrm{A}=$ Assaf. Color version available online.

Cluster analysis supports the results mentioned above. The magnitude of the linkage distances and especially the graphic representations of Figures 5 and 6 show the clusters formed with the whole set of composi-

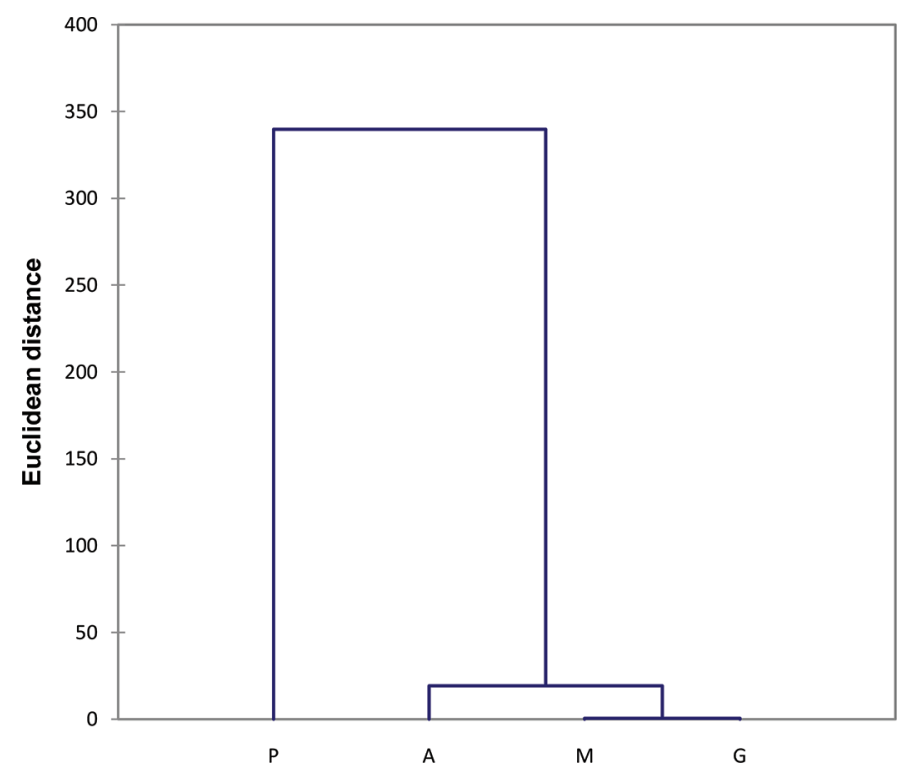

Figure 5. Representation of the results from cluster analysis for the set of milk composition variables. $\mathrm{P}=$ Merino de Los Pedroches, $\mathrm{A}=$ Assaf, $\mathrm{M}=$ Manchega, $\mathrm{G}=$ Merino de Grazalema. Color version available online.

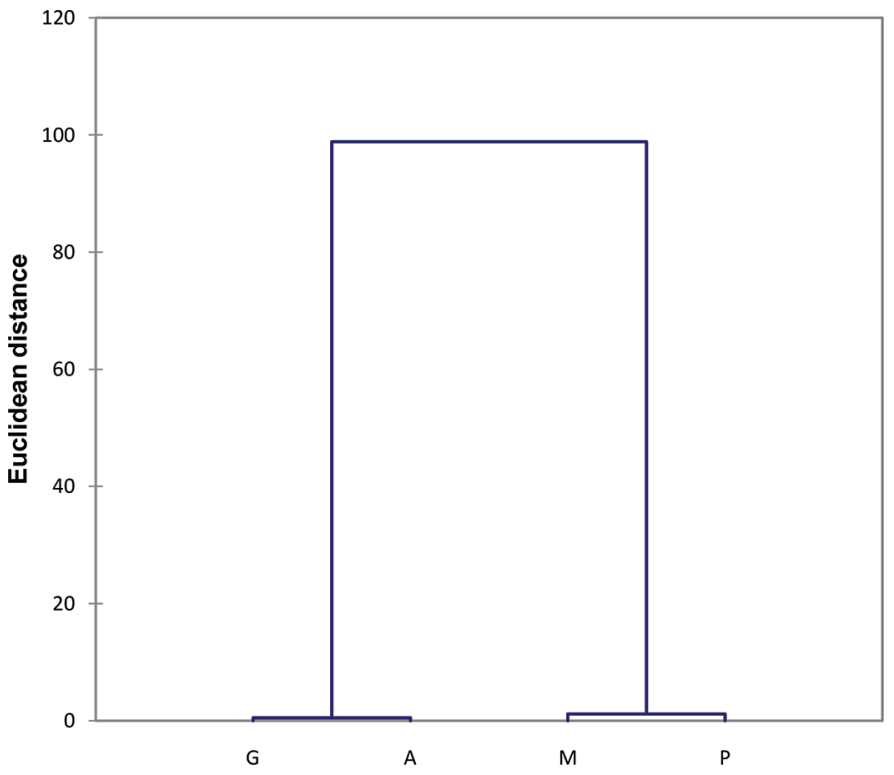

Figure 6. Representation of the results from cluster analysis for the set of milk coagulation variables. $\mathrm{G}=$ Merino de Grazalema, $\mathrm{A}=$ Assaf, $\mathrm{M}=$ Manchega, $\mathrm{P}=$ Merino de Los Pedroches. Color version available online.

tion and coagulation variables, which are in agreement with the results of the canonical discriminant analysis.

The variables with a greater discriminant ability are highlighted in Table 5. For milk composition, the most discriminant variables were lactose, fat, and TS. For milk coagulation, the most discriminant variables were $\mathrm{A}_{60}$ and curd yield. Variables that discriminated between pairs of breeds were identified using stepwise discriminant analysis and Student-Newman-Keuls test (Table 6). The variables fat, TS, and $\mathrm{pH}$ differentiated between all pairs of breeds. The variable with the lower discriminant frequency was curd firming time, as it only differentiated between 2 pairs of breeds.

\section{DISCUSSION}

There has been an increasing interest in the characterization of Spanish dairy sheep breeds, especially toward the development of quality marks such as PDO and PGI (Gaspar et al., 2011). In recent years several authors have focused on morphological variability to characterize different small ruminant breeds (Carneiro et al., 2010; Rodero et al., 2015; Mavule et al., 2016). However, so far, no studies have discriminated between dairy breeds focusing on milk compositional or technological quality. In light of the results obtained in this study, we believe that factors such as the intensification of milk production or the implementation of genetic selection schemes in dairy breeds are not just related 
Table 5. Individual results for the variables included in the canonical discriminant analysis: milk composition, coagulation traits, and both sets of variables (variables with the greatest discriminant ability are shown in bold), and correlations of each variable with the canonical variables (CAN)

\begin{tabular}{|c|c|c|c|c|c|c|c|}
\hline Variable $^{1}$ & $\begin{array}{l}\text { Wilks' } \\
\text { lambda }\end{array}$ & $F$-value & $P$-value & $\mathrm{R}^{22}$ & CAN 1 & CAN 2 & CAN 3 \\
\hline \multicolumn{8}{|l|}{ Both sets } \\
\hline Fat & 0.545 & 230.596 & $<0.0001$ & 0.834 & -0.416 & -0.383 & 0.722 \\
\hline Protein & 0.955 & 13.149 & $<0.0001$ & 0.437 & -0.088 & -0.098 & 0.284 \\
\hline Lactose & 0.235 & 896.767 & $<0.0001$ & 0.605 & 0.920 & 0.306 & -0.068 \\
\hline TS & 0.650 & 148.543 & $<0.0001$ & 0.813 & -0.138 & -0.220 & 0.865 \\
\hline $\mathrm{pH}$ & 0.788 & 74.270 & $<0.0001$ & 0.326 & 0.390 & 0.351 & 0.026 \\
\hline $\mathrm{RCT}$ & 0.906 & 28.700 & $<0.0001$ & 0.290 & 0.065 & -0.325 & -0.200 \\
\hline $\mathrm{K}_{20}$ & 0.950 & 14.441 & $<0.0001$ & 0.320 & -0.024 & 0.164 & -0.275 \\
\hline $\mathbf{A}_{60}$ & 0.610 & 176.521 & $<0.0001$ & 0.405 & 0.424 & -0.579 & 0.119 \\
\hline ILCY & 0.730 & 102.261 & $<0.0001$ & 0.310 & 0.412 & -0.204 & 0.503 \\
\hline $\mathrm{RCT}: \mathrm{A}_{60}$ & 0.989 & 3.073 & 0.027 & 0.272 & 0.042 & 0.082 & -0.110 \\
\hline \multicolumn{8}{|c|}{ Composition } \\
\hline Fat & 0.545 & 230.596 & $<0.0001$ & 0.825 & -0.514 & 0.793 & -0.217 \\
\hline Protein & 0.955 & 13.149 & $<0.0001$ & 0.402 & -0.114 & 0.303 & -0.011 \\
\hline Lactose & 0.235 & 896.767 & $<0.0001$ & 0.487 & 0.977 & -0.057 & -0.093 \\
\hline TS & 0.650 & 148.543 & $<0.0001$ & 0.809 & -0.199 & 0.912 & 0.068 \\
\hline $\mathrm{pH}$ & 0.788 & 74.270 & $<0.0001$ & 0.185 & 0.478 & -0.048 & 0.640 \\
\hline \multicolumn{8}{|c|}{ Coagulation } \\
\hline RCT & 0.906 & 28.700 & $<0.0001$ & 0.251 & 0.298 & -0.402 & -0.076 \\
\hline $\mathrm{K}_{20}$ & 0.950 & 14.441 & $<0.0001$ & 0.304 & -0.158 & -0.232 & 0.799 \\
\hline $\mathbf{A}_{60}$ & 0.610 & 176.521 & $<0.0001$ & 0.330 & 0.743 & 0.118 & -0.024 \\
\hline ILCY & 0.730 & 102.261 & $<0.0001$ & 0.088 & 0.445 & 0.818 & -0.018 \\
\hline $\mathrm{RCT}: \mathrm{A}_{60}$ & 0.989 & 3.073 & 0.027 & 0.263 & -0.44 & -0.035 & 0.528 \\
\hline
\end{tabular}

${ }^{1} \mathrm{RCT}=$ rennet clotting time; $\mathrm{K}_{20}=$ curd firming time; $\mathrm{A}_{60}=$ curd firmness at $60 \mathrm{~min}$; ILCY = curd yield for $10 \mathrm{~mL}$ of milk; RCT: $\mathrm{A}_{60}=$ coagulation efficiency at $60 \mathrm{~min}$.

${ }^{2} \mathrm{R}^{2}=1$ - tolerance

but also determine the quality of ewe milk intended for cheesemaking. In addition, the study of factors other than milk yield should contribute to improve selection decisions in dairy farms (Ramón et al., 2010).

Genetic selection schemes have been implemented for 3 of the studied breeds (except for Merino de Los Pedroches), with Manchega being the breed in which they were first developed (Smulders et al., 2007). According to the results, this breed stands out for producing milk with high fat and protein contents and high yields after coagulation (Table 6). Other authors have also reported these high yields and concentrations of TS in Manchega compared with other native Spanish breeds (Jaramillo et al., 2008). Merino de Grazalema shows a similar composition to Manchega (Figure 5), although coagulation in this breed is not as efficient and curd yields tend to be lower, which was also evidenced when performing cluster analysis (Figure 6). This might be

Table 6. Variables (mean \pm SE) that discriminated between ovine breeds ${ }^{1}(\mathrm{n}=208$ of each breed) using stepwise discriminant analysis and Student-Newman-Keuls test

\begin{tabular}{lcrcr}
\hline Variable $^{2}$ & $\mathrm{M}$ & $\mathrm{G}$ & $\mathrm{P}$ & $\mathrm{A}$ \\
\hline Composition & & & & \\
Fat & & & & \\
Protein & $5.68 \pm 1.30^{\mathrm{b}}$ & $8.55 \pm 1.44^{\mathrm{a}}$ & $6.28 \pm 0.87^{\mathrm{c}}$ & $5.82 \pm 1.15^{\mathrm{d}}$ \\
Lactose & $4.54 \pm 0.43^{\mathrm{c}}$ & $5.78 \pm 0.58^{\mathrm{a}}$ & $5.55 \pm 0.58^{\mathrm{b}}$ & $5.40 \pm 0.58^{\mathrm{c}}$ \\
TS & $19.30 \pm 1.59^{\mathrm{b}}$ & $20.53 \pm 0.29^{\mathrm{c}}$ & $5.97 \pm 0.43^{\mathrm{a}}$ & $4.97 \pm 0.29^{\mathrm{b}}$ \\
pH & $6.62 \pm 0.14^{\mathrm{d}}$ & $6.67 \pm 0.14^{\mathrm{c}}$ & $18.78 \pm 1.87^{\mathrm{c}}$ & $16.83 \pm 1.59^{\mathrm{d}}$ \\
Coagulation & & $6.78 \pm 0.14^{\mathrm{a}}$ & $6.71 \pm 0.14^{\mathrm{b}}$ \\
RCT & $35.38 \pm 7.50^{\mathrm{a}}$ & $26.99 \pm 6.35^{\mathrm{b}}$ & $30.51 \pm 11.83^{\mathrm{c}}$ & $29.83 \pm 10.67^{\mathrm{b}}$ \\
$\mathrm{K}_{20}$ & $3.48 \pm 0.98^{\mathrm{b}}$ & $3.80 \pm 2.16^{\mathrm{b}}$ & $4.19 \pm 1.55^{\mathrm{b}}$ & $7.22 \pm 2.70^{\mathrm{a}}$ \\
$\mathrm{A}_{60}$ & $62.54 \pm 9.37^{\mathrm{a}}$ & $44.02 \pm 6.78^{\mathrm{b}}$ & $60.53 \pm 15.86^{\mathrm{a}}$ & $41.88 \pm 12.69^{\mathrm{b}}$ \\
ILCY $_{\text {RCT:A }}$ & $3.25 \pm 0.58^{\mathrm{b}}$ & $3.15 \pm 0.63^{\mathrm{b}}$ & $3.67 \pm 0.43^{\mathrm{a}}$ & $2.66 \pm 0.39^{\mathrm{c}}$ \\
\hline
\end{tabular}

${ }^{\mathrm{a}-\mathrm{d}}$ Means without a common superscript are statistically different $(P<0.05)$.

${ }^{1} \mathrm{M}=$ Manchega; $\mathrm{G}=$ Merino de Grazalema; $\mathrm{P}=$ Merino de Los Pedroches; $\mathrm{A}=$ Assaf.

${ }^{2} \mathrm{RCT}=$ rennet clotting time; $\mathrm{K}_{20}=$ curd firming time; $\mathrm{A}_{60}=$ curd firmness at $60 \mathrm{~min}$; ILCY $=$ curd yield for $10 \mathrm{~mL}$ of milk; RCT: $\mathrm{A}_{60}=$ coagulation efficiency at $60 \mathrm{~min}$. 
due to the background of selection schemes, widely implemented in Manchega since 1988 (Jurado et al., 2006), whereas in Merino de Grazalema implementation has been more recent (2012) and the scheme mainly focuses on productivity (MAPAMA, 2012). In addition, traditionally Merino was a breed with an aptitude for wool production and changed its husbandry strategy to refocus on meat production (Haenlein, 2007), with milk remaining as a by-product.

Although milk yields in Assaf have been widely reported to be much higher than in other breeds (Jiménez and Jurado, 2015), results comparatively show the lowest concentration of TS in milk, with fat and protein contents similar to those described by other authors (De la Fuente et al., 2006; Milán et al., 2011). Since its introduction in Spain in 1977, the development of Assaf has focused on the improvement of other native breeds through crossbreeding and high milk productivity (Milán et al., 2011); consequently, animal selection regarding the coagulation process has not been contemplated. Thereby, the development of Assaf as a highly productive breed has had a strong effect on coagulation traits, which has resulted in a milk coagulation process with low efficiency. However, intensive systems have been reported to increase profitability in Assaf compared with autochthonous breeds, which seem to be more profitable on more extensive farming systems (De la Fuente et al., 2006). Coexistence of Assaf and Merino de Grazalema in the same cluster when analyzing coagulation variables suggests that the process in both breeds is similar (Figure 6). However, Table 6 shows considerably better values for coagulation traits in Merino de Grazalema (evidenced by lower curd firming times, increased curd firmness, and a reduced RCT/ $\mathrm{A}_{60}$ ratio, which is an indicator of a higher efficiency).

Discriminant analysis revealed Merino de Los Pedroches as the most different group, as values of Mahalanobis distances between this breed and the others were considerably high (Table 3). Means from Table 6 show that milk composition is similar to that from Assaf, but the small Mahalanobis distance for coagulation variables implies that the coagulation process in Merino de Los Pedroches and Manchega is similar, as shown in the cluster represented in Figure 6. However, although milk from Manchega seems to coagulate more efficiently, ILCY in Merino de Los Pedroches is significantly higher. This could be due to the greater lactose concentration in this last breed, which might contribute to an increase of moisture in the curd after draining (Albenzio and Santillo, 2011). Merino de Los Pedroches does not currently participate in any genetic selection scheme. Nevertheless, the fairly good coagulation efficiency and the high curd yields suggest a process of differentiation, which could lay the foundations for its future consolidation as an independent breed in Spain.

\section{CONCLUSIONS}

Production systems and the different approaches and strategies of selection schemes largely determine quality of milk in the studied breeds. Discriminant and cluster analyses have proved to be powerful tools to differentiate between breeds with a high level of accuracy, although milk composition seems to differentiate better between breeds than coagulation traits. However, other Spanish breeds should be considered, and hygienic or sanitary variables are worth including in further analyses to determine their discriminant ability.

\section{ACKNOWLEDGMENTS}

The authors are grateful to the Spanish Association of Manchega Sheep Breeders (AGRAMA, Albacete, Spain), the Association of Merino de Grazalema Breeders (AMEGRA, Villaluenga del Rosario, Cadiz, Spain), the Technological Agricultural Institute of Castilla y León, Spain (ITACYL, Valladolid, Spain), and the farmers of the region Valle de Los Pedroches (Cordoba, Spain) for taking part in this study.

\section{REFERENCES}

Albenzio, M., and A. Santillo. 2011. Biochemical characteristics of ewe and goat milk: Effect on the quality of dairy products. Small Rumin. Res. 101:33-40. https://doi.org/10.1016/j.smallrumres.2011 .09 .023 .

Arias, C., B. Oliete, S. Seseña, L. Jiménez, M. D. Pérez-Guzmán, and R. Arias. 2013. Importance of on-farm management practices on lactate-fermenting Clostridium spp. spore contamination of Manchega ewe milk: Determination of risk factors and characterization of Clostridium population. Small Rumin. Res. 111:120-128. https: //doi.org/10.1016/j.smallrumres.2012.11.030.

Arias, R., B. Oliete, M. Ramón, C. Arias, R. Gallego, V. Montoro, C. Gonzalo, and M. D. Pérez-Guzmán. 2012. Long-term study of environmental effects on test-day somatic cell count and milk yield in Manchega sheep. Small Rumin. Res. 106:92-97. https://doi.org/10 .1016/j.smallrumres.2012.03.019.

Arrebola, F. A. 2004. Caracterización genética de la aptitud lanera del Merino autóctono español. PhD thesis. Universidad de Córdoba, Spain.

Arrebola, F. A., F. Romero, D. Barriga, J. A. Castro, R. García, A. Garzón, and A. Molina. 2007. Efecto sobre la calidad de la leche, características tecnológicas y producción quesera de la raza Merina de Grazalema frente al cruce con razas mejoradas. Pages 33-40 in IV Jornadas ibéricas de razas autóctonas y sus productos tradicionales: Innovación, seguridad y cultura alimentaria, Sevilla, Spain. Consejera de Agricultura y Pesca de la Junta de Andalucia, Sevilla, Spain.

Barillet, F. 2007. Genetic improvement for dairy production in sheep and goats. Small Rumin. Res. 70:60-75. https://doi.org/10.1016/j .smallrumres.2007.01.004.

Bittante, G., A. Cecchinato, N. Cologna, M. Penasa, F. Tiezzi, and M. De Marchi. 2011. Factors affecting the incidence of first-quality 
wheels of Trentingrana cheese. J. Dairy Sci. 94:3700-3707. https:/ /doi.org/10.3168/jds.2010-3746.

Bittante, G., C. Cipolat-Gotet, M. Pazzola, M. L. Dettori, G. M. Vacca, and A. Cecchinato. 2017. Genetic analysis of coagulation properties, curd firming modeling, milk yield, composition, and acidity in Sarda dairy sheep. J. Dairy Sci. 100:385-394. https://doi.org/ $10.3168 /$ jds.2016-11212.

Government of Spain. 2007. Pliego de condiciones de la Denominación de Origen Protegida "Queso Manchego." Boletín Oficial del Estado no 272. Government of Spain, Madrid.

Boyazoglu, J., and P. Morand-Fehr. 2001. Mediterranean dairy sheep and goat products and their quality: A critical review. Small Rumin. Res. 40:1-11. https://doi.org/10.1016/S0921-4488(00)00203 -0 .

Caballero-Villalobos, J., A. I. Garzón, A. L. Martínez Marín, R. Arias, F. Ciocia, and P. L. H. McSweeney. 2018b. Plasmin activity in Manchega ewe milk: The effect of lactation, parity and health of the udder, and its influence on milk composition and rennet coagulation. Small Rumin. Res. 158:57-61. https://doi.org/10.1016/ j.smallrumres. 2017.10.005.

Caballero-Villalobos, J., J. M. Perea, E. Angón, R. Arias, and A. Garzón. 2018. Coagulation efficiency and its determinant factors: A case study for Manchega ewe milk in the region of Castilla-La Mancha, Spain. J. Dairy Sci. 101:3878-3886. https://doi.org/10 $.3168 /$ jds.2017-13816.

Carneiro, H., H. Louvandini, S. R. Paiva, F. Macedo, B. Mernies, and C. McManus. 2010. Morphological characterization of sheep breeds in Brazil, Uruguay and Colombia. Small Rumin. Res. 94:58-65. https://doi.org/10.1016/j.smallrumres.2010.07.001.

Casas, J. P., R. Torres, P. J. Azor, M. Valera, and A. Molina. 2005. Programa de recuperación de la oveja Merina de Grazalema: Caracterización genético-productiva. Pages 125-127 in XXX Jornadas Científicas y IX Internacionales de la Sociedad Española de Ovinotecnia y Caprinotecnia (SEOC), Granada, Spain. Consejeria de Agricultura y PEsca de la Junta de Andalucia, Sevilla, Spain.

De la Fuente, L. F., D. Gabiña, N. Carolino, and E. Ugarte. 2006. The Awassi and Assaf breeds in Spain and Portugal. Page 79 in 57th Annual Meeting of the European Association for Animal Production (EAAP), Antalya, Turkey.

ESROM. 2015. Memoria del Esquema de Selección de la raza ovina Manchega. Año 2015. AGRAMA, Albacete, Spain.

Everitt, B. S., and G. Dunn. 1991. Applied Multivariate Data Analysis. Arnold, London, UK.

FAOSTAT. 2018. Livestock primary. Accessed Mar. 5, 2018. http:// www.fao.org/faostat/en/\#data/QL.

Gallego, R., O. García, R. Arias, M. D. Pérez-Guzmán, and V. Montoro. 2016. Evolution of the breeding program of the Manchega dairy sheep white variety. Achievements and results. Arch. Zootec. 65:437-440.

García Romero, C., M. Orellana, J. A. Castro Mateos, and C. GarcíaRomero Moreno. 2017. Raza ovina Merina de Grazalema. Agricultura Ganadería Ecológica 29:59.

Gaspar, P., A. J. Escribano, F. J. Mesías, M. Escribano, and A. F. Pulido. 2011. Goat systems of Villuercas-Ibores area in SW Spain: Problems and perspectives of traditional farming systems. Small Rumin. Res. 97:1-11. https://doi.org/10.1016/j.smallrumres.2011 .03 .001

Haenlein, G. F. W. 2007. About the evolution of goat and sheep milk production. Small Rumin. Res. 68:3-6. https://doi.org/10.1016/j .smallrumres.2006.09.021.

Herrera, M., E. Rodero, M. J. Gutiérrez, F. Peña, and J. M. Rodero. 1996. Application of multifactorial discriminant analysis in the morphostructural differentiation of Andalusian caprine breeds. Small Rumin. Res. 22:39-47. https://doi.org/10.1016/0921 $-4488(96) 00863-2$.

Inlac. 2015. El sector lácteo en España: Datos de producción, industria y consumo. Accessed May 2018. http://www.inlac.es/admin/ uploads/files/id_20173418_Informesocioeconomicoinlac20.09.16 .pdf

Jaramillo, D., A. Zamora, B. Guamis, M. Rodríguez, and A. J. Trujillo. 2008. Cheesemaking aptitude of two Spanish dairy ewe breeds:
Changes during lactation and relationship between physico-chemical and technological properties. Small Rumin. Res. 78:48-55. https://doi.org/10.1016/j.smallrumres.2008.04.005.

Jiménez, M. A., and J. J. Jurado. 2015. Study of quality of pedigree from Assaf breed in Spain. Información Técnica Económica Agraria 111:247-258. https://doi.org/10.12706/itea.2015.016.

Jurado, J. J., M. Serrano, and M. D. Pérez-Guzmán. 2006. Analysis of the genetic progress obtained in the selection program in Manchega sheep breed. Información Técnica Económica Agraria 102:41-54

Legaz, E., I. Cervantes, M. A. Pérez-Cabal, L. F. De la Fuente, R. Martínez, F. Goyache, and J. P. Gutiérrez. 2011. Multivariate characterisation of morphological traits in Assaf (Assaf.E) sheep. Small Rumin. Res. 100:122-130. https://doi.org/10.1016/j.smallrumres 2011.06.005.

MAPAMA (Ministerio de Agricultura y Pesca, Alimentación y Medio Ambiente). 2012. Programa de mejora de la raza ovina Merina de Grazalema. Accessed May 2018. http://www.mapama.gob.es/es/ ganaderia/temas/zootecnia/Anexo_II_PM_Ovina.M.Grazalema _tcm7-299691.pdf.

MAPAMA (Ministerio de Agricultura y Pesca, Alimentación y Medio Ambiente). 2018. Razas de ganado del Catálogo Oficial de España. Accessed June 2018. http://www.mapama.gob.es/es/ganaderia/ temas/zootecnia/razas-ganaderas/publicaciones-interes/Razas_de ganado_del_catalogo_web_tcm7-306058.pdf.

Mavule, B. S., F. M. Sarti, E. Lasagna, and N. W. Kunene. 2016. Morphological differentiation amongst Zulu sheep populations in KwaZulu-Natal, South Africa, as revealed by multivariate analysis. Small Rumin. Res. 140:50-56. https://doi.org/10.1016/j .smallrumres.2016.06.001.

McMahon, D., and R. Brown. 1982. Evaluation of Formagraph for comparing rennet solutions. J. Dairy Sci. 65:1639-1642.

Milán, M. J., G. Caja, R. González-González, A. M. Fernández-Pérez, and X. Such. 2011. Structure and performance of Awassi and Assaf dairy sheep farms in northwestern Spain. J. Dairy Sci. 94:771-784. https://doi.org/10.3168/jds.2010-3520.

Molina, A., J. P. Casas, P. Azor, M. Valera, J. A. Jaén, and R. Torres. 2005. Productive and demographic characteristics of the Grazalema Merina sheep breed. Pages 324-327 in Animal Production and Natural Resources Utilisation in the Mediterranean Mountain Areas. EAAP Publication No. 115. Wageningen Academic Publishers, Wageningen, the Netherlands. https://doi.org/10.3920/ 978-90-8686-561-1.

Morantes, M., R. Dios-Palomares, M. E. Peña, J. Rivas, J. Perea, and A. García-Martínez. 2017. Management and productivity of dairy sheep production systems in Castilla-La Mancha, Spain. Small Rumin. Res. 149:62-72. https://doi.org/10.1016/j.smallrumres.2017 .01 .005 .

Moreno, I., and E. Aguilar Criado. 2012. Quality labeling and territorial development: The cases of sheep cheese from Merino de Grazalema and lamb meet from Cordero de Texel. Rev. Econom. Agríc. 59:131-149.

Ordiales, E., A. Martín, M. J. Benito, A. Hernández, S. Ruiz-Moyano, and M. G. Córdoba. 2013. Role of the microbial population on the flavor of the soft-bodied cheese Torta del Casar. J. Dairy Sci. 96:5477-5486. https://doi.org/10.3168/jds.2013-6587.

Othmane, M. H., J. A. Carriedo, L. F. De la Fuente Crespo, and F. San Primitivo. 2002. An individual laboratory cheese-making method for selection in dairy ewes. Small Rumin. Res. 45:67-73. https://doi.org/10.1016/S0921-4488(02)00079-2

Pazzola, M., C. Cipolat-Gotet, G. Bittante, A. Cecchinato, M. L. Dettori, and G. M. Vacca. 2018. Phenotypic and genetic relationships between indicators of the mammary gland health status and milk composition, coagulation and curd firming in dairy sheep. J. Dairy Sci. 101:3164-3175. https://doi.org/10.3168/jds.2017-13975.

Pazzola, M., M. L. Dettori, C. Cipolat-Gotet, A. Cecchinato, G. Bittante, and G. M. Vacca. 2014. Phenotypic factors affecting coagulation properties of milk from Sarda ewes. J. Dairy Sci. 97:72477257. https://doi.org/10.3168/jds.2014-8138.

Pérez-Cabal, M. A., E. Legaz, I. Cervantes, L. F. De la Fuente, R. Martínez, F. Goyache, and J. P. Guitiérrez. 2013. Association be- 
tween body and udder morphological traits and dairy performance in Spanish Assaf sheep. Arch. Tierzucht 56:430-442. https://doi .org/10.7482/0003-9438-56-042.

Ramón, M., A. Legarra, E. Ugarte, J. J. Garde, and M. D. PérezGuzmán. 2010. Economic weights for major milk constituents of Manchega dairy ewes. J. Dairy Sci. 93:3303-3309. https://doi.org/ 10.3168/jds.2009-2787.

European Union. 2015. Regulation 625 of 20 April 2015, approving non-minor amendments to the specification for a name entered in the register of protected designations of origin and protected geographical indications [Queso Zamorano (PDO)].

Rivas, J., A. García, P. Toro-Mújica, E. Angón, J. Perea, M. Morantes, and R. Dios-Palomares. 2014. Technical, social and commercial profile of the Manchega dairy sheep farms in South-Central Spain. Rev. Mex. Cienc. Pecu. 5:291-306.

Rodero, E., A. González, M. Dorado-Moreno, M. Luque, and C. Hervás. 2015. Classification of goat genetic resources using morphological traits. Comparison of machine learning techniques with linear discriminant analysis. Livest. Sci. 180:14-21. https://doi .org/10.1016/j.livsci.2015.06.028.

Rodero, E., A. González, M. Luque, M. Herrera, and J. C. GutiérrezEstrada. 2012. Classification of Spanish autochthonous bovine breeds. Morphometric study using classical and heuristic techniques. Livest. Sci. 143:226-232. https://doi.org/10.1016/j.livsci .2011.09.022.

Smulders, J. P., M. Serrano, M. D. Pérez-Guzmán, M. A. Jimenez, H. Uribe, and J. J. Jurado. 2007. Stochastic simulation of Manchega sheep breed selection scheme. Impact of artificial insemination, progeny testing system and nucleus size on genetic progress and inbreeding. Livest. Sci. 106:218-231. https://doi.org/10.1016/j.livsci 2006.08.008.

Tabachnick, B. G., and L. S. Fidell. 1996. Using Multivariate Statistics. 3rd ed. Harper Collins, New York, NY.

Toro-Mujica, P., A. García, A. G. Gómez-Castro, R. Acero, J. Perea, V. Rodríguez-Estévez, C. Aguilar, and R. Vera. 2011. Technical efficiency and viability of organic dairy sheep farming systems in a traditional area for sheep production in Spain. Small Rumin. Res. 100:89-95. https://doi.org/10.1016/j.smallrumres.2011.06.008.

Zurita-Herrera, P., J. V. Delgado, A. Argüello, and M. E. Camacho. 2011. Multivariate analysis of meat production traits in MurcianoGranadina goat kids. Meat Sci. 88:447-453. https://doi.org/10 .1016/j.meatsci.2011.01.025. 